\title{
CONCEPTUALISATION OF MANAGEMENT AND LEADERSHIP
}

\author{
Dr Hester Nienaber, Department of Business Management, Unisa \\ nienah@unisa.ac.za
}

Tel +27 12 429-2994

\begin{abstract}
ABSATRACT
The divide in the conceptualisation of the terms "management" and "leadership" is not clear. The purpose of the study on which this article is based was to explore the concepts of management and leadership. The synthesis review also applied content analysis, identifying the tasks constituting management and leadership respectively.
\end{abstract}

The findings of the literature review demonstrated that the concepts of management and leadership are intertwined. The word "management" has French and Italian roots, while the word "leadership" has Greek and Latin roots. Essentially, though, these words are synonymous. All of the tasks fall within the boundaries of management, while leadership tasks overlap with management. Unlike management, leadership has no distinct task that falls exclusively within its boundary.

Implications of the findings of this study include debate regarding how practising managers can know what is expected of them if the literature is unclear on the distinction between these concepts.

\section{INTRODUCTION}

The first publication in the field of management appeared almost two centuries ago, in 1825. Originally, management was considered from the perspective of the "general manager" of a business and it specifically addressed the tasks he/she had to discharge to ensure the success of the business. In the beginning, these tasks were classified into five broad categories, namely planning, organising, command, coordination and control with each comprising a host of activities (Fayol, 1916). These tasks were deemed to constitute the primary tasks of management, with communication, motivation and decisionmaking as secondary management tasks. At the time, the terms "manager" and 
"leader" were used interchangeably to denote the person with ultimate responsibility for the performance of the firm. In later years, the responsibilities of command and coordination were collapsed into leadership, which was still treated as a primary task of general management. Today these tasks are still deemed to constitute management.

More recently, a number of works on leadership have appeared, suggesting that leadership is a separate and distinct function in the firm (see, for example, Armandi, Oppedisano and Sherman, 2003; Bennis and Nanus, 1985; Burns, 1978; Kent, Crotts and Azziz, 2001; Kotter, 1996; 2001; Pearce, Sims, Cox, Ball, Schnell, Smith and Trevino, 2003; Tichy, 1997; Zaleznik, 1977). The works of Zalesnik (1977) and Burns (1978), in particular, seem to present the watershed between management and leadership, with leadership being an exalted concept that is indispensable for the successful performance of the firm. According to these works, management is portrayed as mundane, uninspiring and tactical by nature, and cannot guarantee the success of the business. As such, it is proposed that leadership be favoured at the expense of management (see for example Spurgeon and Cragg, 2007) - which seems to be an outdated concept - in order to ensure business success.

A number of authors support the differentiation between management and leadership, although the basis of this differentiation is not clear (see, for example, Ulrich, Zenger and Smallwood, 1999). However, there is another trend where authors (Fells, 2000; Ghoshal, 2005; Humphreys and Einstein, 2003; McMahon and Carr, 1999; Nienaber and Roodt, 2008; Novicevic, Sloan, Duke, Holmes and Breland, 2006; Payne, Youngcourt and Watrous, 2006; Stewart, 1985; Wagner-Tsukamoto, 2007; Washbush, 2005; Wren, 2005) treat management and leadership as an integrated whole, as do the seminal management authors (Barnard, 1938; Fayol, 1916; Follett, 1925, 1933a and b).

Ever since the first publication on leadership, there has been an ongoing debate about the relevance and significance of management and its role in the success of the business relative to that of leadership. On examining the management and leadership literature, it appears that both concepts are concerned with the overall success of the business. Despite the continuing debate, a conclusive answer as to the respective roles and 
significance of management and leadership in the success of the business seems evasive.

Further scrutiny of the management and leadership literature reveals a gap in comparing the content of management and leadership and their respective role(s) in the success of the business. Is either one more important than the other, and if so, to what extent; and are these concepts mutually exclusive or complementary? With the current global economic recession, information about the respective role(s) and place of management and leadership in the successful performance of the business can stand both academics and practitioners in good stead.

Given the divide between management and leadership (in the literature), this article seeks to compare the content of management and leadership, as it appears in the literature. To achieve the purpose of this article, a comprehensive literature review, utilising a synthesis review and content analysis, is presented. This article closes with conclusions and recommendations.

\section{MANAGEMENT AND LEADERSHIP CONTENT}

The literature review sets out to identify the content of management and leadership and is based on the approach described by Kirkevold (1997) as a synthesis review. This type of review integrates isolated information into a more comprehensive and internally consistent whole. It thus facilitates the integration of separate studies with different focuses and uses a variety of methodologies to provide a comprehensive account of the phenomenon being reviewed. This type of review is a powerful knowledgedevelopment tool as it enables knowledge to be accumulated that goes beyond merely evaluating the strength and weaknesses of existing knowledge to create a whole new and more informative understanding of the phenomenon studied (Kirkevold, 1997). In addition, content analysis was employed to arrive at the content of management and leadership, as proposed by Berelson and Bernard (1952). Essentially, content analysis scrutinises communication for the presence, meaning and relationships of certain words and/or phrases to make inferences about the message communicated. According to Kent (2005), the literature in the field of leading and managing is becoming increasingly 
fragmented. As such, the synthesis review and conceptual analysis are deemed the most appropriate approaches for this conceptual study.

\section{The search methods}

The literature search followed the typical format of a literature review in research (Babbie, 2007; Creswell, 2009). The search was of recent literature, from 2004 until 2009. In addition, original works of "evergreens" were included as significant sources indicated by recent publications. Original texts were consulted as they provide a verifiable history and not historical conjecture (Wrege, Greenwood and Hata, 1999). The databases searched were ProQuest, EBSCOHost, Emerald and SABINET, which enabled searches in many different journals. ProQuest (ABI/INFORM) searched more than 3000 periodicals, EBSCOHost (Business Source Complete) explored more than 1200 journals, Emerald investigated more than 200 journals and SABINET covered more than 800 journals. These databases were considered to be the leading databases in business and management. The search terms used were "management", "general management”, "leadership", “origin/development/evolution/history/future of (general) management/leadership", "management/leadership theory/practice" and "management/leadership gap/difference". In addition, Google Scholar was used to identify authors - including those with a high citation - prescribed texts at higher education institutions and the pioneers discussed in these management and leadership texts. Points of view included those of top management and/or "shop floor" (Parayitam, White and Hough, 2002). The following inclusion criteria for literature sources were applied:

- the work reported on the content of management/leadership

- the work reported on the tasks and/or activities of management/leadership

- the work reported on what managers/leaders do

- $\quad$ the work reported on differences between management and leadership

- $\quad$ the work reported on similarities between management and leadership

- the origin/history/evolution/development/future of the concepts of management and leadership 
The 80 works reviewed may not be all-inclusive, but they do represent a range of management and leadership work and cover various aspects, which will be dealt with in the literature review. Topics include the linguistic origin and meaning of the terms in their contemporary subject matter-specific interpretation; the hierarchical levels in the organisation, from the shop floor to executive management positions; and the contributions of practitioners to academia, and research results to viewpoints adopted.

\section{A long history of management and leadership but no clarity}

Leadership, as a broad construct, has existed from the dawn of the first interactions of humankind (Humphreys, 2005), while management has been practised since time immemorial - as is evident from records from early civilisations (Hodgetts, 1975; Witzel, 2002; Wren 2005). However, the documented body of knowledge pertaining to leadership and management is relatively new (Nienaber and Roodt, 2008). This is consistent with the view of Grace (2003), who indicates that the root word of "leadership" (Greek and Latin) dates back to $800 \mathrm{CE}$ (Common Era), while the root word of "management" (French) appeared in 1598 CE. The concept of management of people had appeared in the textual records by 1809, 30 years before the word "leadership" (Grace, 2003). Since the twentieth century, these terms have been associated with the discipline of management and leadership (Grace, 2003).

When first documented, the meaning of "lead" was to "cause or go along with oneself, to bring a person or animal to a place", and it included a differentiation between leading and execution. The difference between "leading" and "execution" is a continuation of the idea of Plato, namely that knowing what to do and doing it are two different things. Much later (1828), the concepts of exerting an influence and exercising domination were introduced to the definition of "leading" (Grace, 2003). The linguistic meaning of "leadership" also implied a hierarchical position and includes the relationship between leader and followers. This view is congruent with the views of Barnard (1938), Bennis and Nanus (1985), Burns (1978), Horner (1997), Kotter (2001), Novicevic, Davis, Dorn, Buckley and Brown (2005), Von Krogsik (2007) and Zaleznik (1977), who regarded leaders as being superior to followers or those in subordinate positions. Follett (1933a and b) points out that leadership is a personal quality which can be exercised by many 
people, not only top executives. She continues by iterating that the higher the person is in the hierarchy, the more quality is required, especially in terms of the "total situation" (Follett, 1933a). The "total situation", according to Follett (1933a), includes fragmented facts, present and potential, aims, purposes, people, experiences and desires from which the leader must find a unifying whole, seeing relationships between all the different parts. It stands to reason that the higher the hierarchical position, the "more ability of this kind is required by the leader as a wider range of facts are manifest from which to seize relations" (Follett, 1933a). At the same time she highlights the changing nature of this "ability", as dictated by the situation, to ensure the success of the organisation. This "ability" notion of Follett is consistent with the view that leadership portrays a leader as a great person endowed with unique qualities which could influence or overpower subordinates to discharge their responsibilities (Grace, 2003). The linguistic meaning of leadership corresponds with its application in contemporary leadership studies (Barnard, 1938; Bennis and Nanus, 1985; Burns, 1978; Horner, 1997; Kotter, 2001; Novicevic, Davis, Dorn, Buckley and Brown, 2005; Von Krogsik, 2007; Zaleznik, 1977).

In the case of the term "manager", the word was originally associated with a person who handles horses (Grace, 2003). In later years, the word "manager" appeared in the literature in relation to the British Houses of Parliament and was described as "a member of a committee appointed by one house to confer with a similar committee in the other house", indicating a shift in meaning. Generally, the contemporary use of the word "manager" coincides with the linguistic development of the term, which also corresponds with its historic development. Since the appearance of the first publication on management in 1825, a number of management scientists (Babbage, 1832; Barnard, 1938; Church and Alfred, 1912; Drucker, 1955; Follett, 1925 and 1933a; Ghoshal, 2005; Gilbreth, 1914; Gilbreth, 1922; Humphreys and Einstein, 2000; Koontz and Weihrich, 1988; McGregor, 1966a and b; McMahon and Carr, 1999; O'Connor, 2000; Owen, 1825; Reese and Porter, 2008; Sheldon, 1923; Simon, 1962; Taylor, 1911; Wren, 2005) have pointed out that management requires special skills to deal with individuals who have a will of their own. The latter should be treated as mature adults who can make a contribution to the organisation, rather than trying to drive them by fear, as businesspeople did in the pre-Renaissance era. Despite the efforts to inform scholars 
and practitioners accurately about management, Rousseau (2006) points out that it would seem that, in contemporary times, some managers - including those with master's of business administration (MBA) degrees - rely largely on personal experience, to the exclusion of more systematic knowledge, which is contrary to scientific understanding. This observation supports the view of Parker and Ritson (2005), who point out the susceptibility of the management discipline to fads and willingness to accept contradictions that other scientific disciplines would deem intolerable. This shortcoming is compounded by the current generation of students who read less of the actual writings of the early scholars and more of what is attributed to them by current texts (McMahon and Carr, 1999). This may lead to the early authors being misinterpreted (Gibreth, 1914). Lamond (2005) supports this observation and goes further to suggest that management authors who have a voice in the literature do not necessarily comply with criteria such as rationality, objectivity and validity. These values are usually characteristic of scholars. This state of affairs obfuscates the real meaning of the concepts "management" and "leadership".

In contemporary times, the terms "leadership" and "management" are often used interchangeably (Kent, Crotts, Azziz, 2001; Kent, 2005; also see the works of Barnard, 1938; Fayol, 1916; Follett, 1925, 1933a; Novicevic et al., 2005; Wren, 2005). Although the interchangeability of these terms may hamper clarity in some respects, it seems to correspond with the linguistic explanation provided by Grace (2003), who notes that the introduction of the concept "leadership" in organisations is indicated to be synonymous with "management". Despite this observation and numerous studies on management and leadership indicating that these terms are the same - or at least related (Barnard, 1938; Bass in an interview with Kidwell, 2005; Chapman, 2001; Fayol, 1916; Kent, 2005; Lamond, 2005; Sheldon, 1923; Spurgeon and Cragg, 2007; Stewart, 1989; Washbush 2005; Wren, 2005) - there still seem to be divergent views on these concepts (see, for example, Burns, 1978; Kotter 2001; Zalesnik, 1977).

These conflicting views are examined in the next section of the article, which deals with the content of management and leadership literature studied. 


\section{Content analysis of leadership and management literature}

In reviewing the literature on management and leadership, it became apparent that some authors assume that management is represented exclusively by the view of Taylor (see, for example, Kotter, 2001; Kent, 2005; Toor and Ofori, 2008). Taylor (1911) wrote from the view of the shop floor, which is a front-line position (in today's terms). Barnard (1938, 1948), Fayol (1916) and Follett (1925; 1933a and b), on the other hand, wrote from the point of view of top management - the chief executive or general manager. Tasks, roles and responsibilities at the different hierarchical levels differ when comparing the views of Barnard (1938) and Fayol (1916) with those of Taylor (1911). This view is supported by Sheldon (1923), who points out that management proper (the execution of policy) is subordinate to administration (the formulation of policy). In applying content analysis to these leadership and management works studied, irrespective of hierarchical level in the organisation, certain themes relating to management and leadership tasks emerged. These activities are listed in table 1, which also shows which author(s) mention the activity. These themes or tasks relate to the organisation as such, the staff in the organisation who are responsible for the output of the organisation, and the environment within which the organisation operates. As a number of tasks are interrelated, they are not listed separately but are discussed after the table. 
Table 1: Summary of tasks as presented in management and leadership literature

\begin{tabular}{|c|c|c|}
\hline Task & Management authors & Leadership authors \\
\hline $\begin{array}{l}\text { 1. Assume responsibility for the } \\
\text { survival and growth of the } \\
\text { business. }\end{array}$ & $\begin{array}{l}\text { Barnard, 1938; 1948; Bruch and Ghoshal, 2004; Daft and Marcic, } \\
\text { 2006; Drucker, 1955; 1989; 2003; Fayol, 1916; Follett, } 1925 \text { and } \\
\text { 1933a; Hellriegel, Jackson, Slocum, Staude, Amos, Klopper, Louw } \\
\text { and Oosthuizen, 2008; McGregor, 1966a; Reese and Porter, 2008; } \\
\text { Storey and Salaman, 2005; Wren, 2005 }\end{array}$ & Tichy, 1997; Ulrich et al., 1999 \\
\hline 2. Anticipate the future. & $\begin{array}{l}\text { Barnard, 1938; Bruch and Ghoshal, 2004; Daft and Marcic, 2006; } \\
\text { Drucker, 1955; 1989; 2003; Fayol, 1916; Follett, 1925; 1933a; } \\
\text { Hellriegel et al., 2008; Reese and Porter, 2008; Stewart, 1985; } \\
\text { Wren, } 2005\end{array}$ & Ulrich et al., 1999 \\
\hline $\begin{array}{l}\text { Set direction, including } \\
\text { establishing } \\
\text { 3. an organisational vision } \\
\text { 4. a mission } \\
\text { 5. goals } \\
6 . \quad \text { strategy }\end{array}$ & $\begin{array}{l}\text { Barnard, 1938; Barnard, 1948; Bruch and Ghoshal, 2004; Daft and } \\
\text { Marcic, 2006; Drucker, 1955; 1989; 2003; Emerson, 1912; Fayol, } \\
\text { 1916; Follett, } 1925 \text { and 1933a; Gilbreth, 1922; Hellriegel et al., } \\
\text { 2008; Hopf, 1935; McGregor, } 1966 \text { (b); Reese and Porter, 2008; } \\
\text { Robb, 1910; Sheldon, 1923; Simon, 1962; Stewart, 1985; Storey } \\
\text { and Salaman, 2005; Wren, 2005 }\end{array}$ & $\begin{array}{l}\text { Bennis and Nanus, 1985; } \\
\text { Collins, 2001; Daft, 2008; Kent, } \\
\text { 2005; Kotter, 2001; Tichy, 1997; } \\
\text { Ulrich, Zenger and Smallwood, } \\
1999\end{array}$ \\
\hline 9. Determine priorities. & $\begin{array}{l}\text { Barnard, 1948; Bruch and Ghoshal, 2004; Daft and Marcic, 2006; } \\
\text { Drucker, 1955; 1989; 2003; Fayol, 1916; Follett, } 1925 \text { and1933a }\end{array}$ & $\begin{array}{l}\text { Ulrich, Zenger and Smallwood, } \\
1999\end{array}$ \\
\hline
\end{tabular}




\begin{tabular}{|c|c|c|}
\hline & $\begin{array}{l}\text { and b; Gantt, 1919; Hellriegel et al., 2008; McGregor, } 1966 \text { (b); } \\
\text { Mintzberg, 1973; Robb, 1910; Reese and Porter, 2008; Storey and } \\
\text { Salaman, 2005 }\end{array}$ & \\
\hline $\begin{array}{l}\text { 10. Determine what goods and } \\
\text { services customers desire, } \\
\text { including the price they are willing } \\
\text { to pay. }\end{array}$ & $\begin{array}{l}\text { Barnard, 1938; Bruch and Ghoshal, 2004; Chapman, 2001; Daft } \\
\text { and Marcic, 2006; Drucker, 1955; 1989; 2003; Fayol, 1916; } \\
\text { Follett, 1925; Hellriegel et al., 2008; Reese and Porter, 2008; } \\
\text { Sheldon, 1923; Simon, } 1962\end{array}$ & $\begin{array}{l}\text { Ulrich, Zenger and Smallwood, } \\
1999\end{array}$ \\
\hline $\begin{array}{l}\text { Determine organisational } \\
\text { performance in terms of } \\
\text { 11. organisational view }(f=\{\text { ability, } \\
\text { motivation, opportunity }\}) \\
\text { 12. customer view }(f=\{\text { opinion of } \\
\text { value obtained }\})\end{array}$ & $\begin{array}{l}\text { Babbage, 1832; Bruch and Ghoshal, 2004; Church and Alfred, } \\
\text { 1912; Daft and Marcic 2006; Drucker, 1955; 1989; 2003; } \\
\text { Emerson, 1912; Fayol, 1916; Follett, 1925; Gilbreth, 1914; } \\
\text { Gilbreth, 1922; Gantt, 1908; Hellriegel et al., 2008; McGregor, } \\
1966 \text { (a) and (b); Moss-Kanter, 1997; Owen, 1813; Reese and } \\
\text { Porter, 2008; Sheldon, 1923; Taylor, 1911 }\end{array}$ & \\
\hline $\begin{array}{l}\text { 13. Understand the environment in } \\
\text { which the business operates } \\
\text { (macro, market, micro). }\end{array}$ & $\begin{array}{l}\text { Barnard, 1938; Bruch and Ghoshal, 2004; Collins, 2001; Daft and } \\
\text { Marcic, 2006; Drucker, 1955; 1989; 2003; Emerson, 1912; Fayol, } \\
\text { 1916; Follett, 1925 and 1933a; Gilbreth, 1922; Hellriegel et al., } \\
\text { 2008; McGregor, 1966b; Mendenhall, Macomber and Cutright, } \\
\text { 2000; Moss-Kanter, 1997; Reese and Porter, 2008; Simon, 1962; } \\
\text { Stewart, 1985; Storey and Salaman, } 2005\end{array}$ & $\begin{array}{l}\text { Tichy, 1997; Ulrich, Zenger and } \\
\text { Smallwood, } 1999\end{array}$ \\
\hline $\begin{array}{l}\text { Maintain an information base to } \\
\text { 15. establish needs } \\
\text { 16. gather and evaluate information } \\
\text { 17. use information }\end{array}$ & $\begin{array}{l}\text { Barnard, 1948; Church and Alfred, 1912; Daft and Marcic, 2006; } \\
\text { Drucker, 1955; 1989; 2003; Fayol, 1916; Follett, 1925; } \\
\text { Gantt,1908; Gehani, 2007; Gilbreth, 1922; Hellriegel et al., 2008; } \\
\text { Metcalfe, 1885; Mintzberg, 1973; Moss-Kanter, 1997; Reese and } \\
\text { Porter, 2008; Simon, 1962; Stewart, 1985; Storey and Salaman, } \\
\text { 2005; Towne, 1886 }\end{array}$ & \\
\hline Create and & Babbage, 1832; Barnard, 1938; Barnard, 1948; Chapman, 2001; & Bennis and Nanus, 1985; Burns, \\
\hline
\end{tabular}




\begin{tabular}{|c|c|c|}
\hline $\begin{array}{l}\text { environment in which employees } \\
\text { can perform by } \\
\text { 18. honing their abilities to ensure that } \\
\text { they can achieve their full } \\
\text { potential } \\
\text { 19. contracting with workers in a way } \\
\text { that is advantageous to both them } \\
\text { and the firm } \\
\text { 20. empowering employees so that } \\
\text { they can discharge their } \\
\text { responsibilities effectively } \\
\text { 21. } \begin{array}{l}\text { considering the emotions of staff, } \\
\text { which contributes to building trust }\end{array}\end{array}$ & $\begin{array}{l}\text { Church and Alfred, 1912; Daft and Marcic, 2006; Drucker, 1955; } \\
\text { 1989; 2003; Fayol, 1916; Follett, 1925; Gantt, 1908; Gilbreth, } \\
\text { 1922; Hellriegel et al., 2008; Humphreys and Einstein, 2003; } \\
\text { McGregor, 1966a and b; Metcalfe, 1885; Moss-Kanter, 1997; } \\
\text { Owen, 1825; Reese and Porter, 2008; Simon, 1962; Taylor, 1911; } \\
\text { Towne, 1886 }\end{array}$ & $\begin{array}{l}\text { 1978; Kotter, 2001; Ulrich, } \\
\text { Zenger and Smallwood, } 1999\end{array}$ \\
\hline $\begin{array}{l}\text { 22. Select a competitive arena to } \\
\text { compete. }\end{array}$ & $\begin{array}{l}\text { Barnard, 1948; Daft and Marcic, 2006; Drucker, 1955; 1989; } \\
\text { 2003; Emerson, 1912; Fayol, 1916; Follett, 1925; Hellriegel, et al., } \\
\text { 2008; Reese and Porter, } 2008\end{array}$ & $\begin{array}{l}\text { Ulrich, Zenger and Smallwood, } \\
1999\end{array}$ \\
\hline $\begin{array}{l}\text { 23. Determine what constitutes } \\
\text { customer value. }\end{array}$ & $\begin{array}{l}\text { Barnard, 1948; Bruch and Ghoshal, 2004; Drucker, 1955; 1989; } \\
\text { 2003; Fayol, 1916; Follett, 1925; Hellriegel et al., 2008; Reese and } \\
\text { Porter, 2008; Simon, } 1962\end{array}$ & $\begin{array}{l}\text { Ulrich, Zenger and Smallwood, } \\
1999\end{array}$ \\
\hline $\begin{array}{l}\text { 24. Ensure access to required } \\
\text { knowledge, skills, assets, } \\
\text { resources and processes so that } \\
\text { value is provided to customers in } \\
\text { the chosen arena. }\end{array}$ & $\begin{array}{l}\text { Babbage, 1832; Barnard, 1938; Bruch and Ghoshal, 2004; } \\
\text { Drucker, 1955; 1989; 2003; Fayol, 1916; Follett, 1925; Gantt, } \\
\text { 1908; Gehani, 2002; Hellriegel et al., 2008; McGregor, 1966 (a) } \\
\text { and (b); Moss-Kanter, 1997; Owen, 1825; Reese and Porter, 2008; } \\
\text { Robb, 1910; Taylor, 1911; Storey and Salaman, 2005; Towne, } \\
\text { 1886 }\end{array}$ & $\begin{array}{l}\text { Collins, 2001; Ulrich, Zenger } \\
\text { and Smallwood, } 1999\end{array}$ \\
\hline $\begin{array}{l}\text { 25. Ensure adherence to the principles } \\
\text { of productivity in accomplishing } \\
\text { the goals of the business. }\end{array}$ & $\begin{array}{l}\text { Babbage, 1832; Bruch and Ghoshal, 2004; Church and Alfred, } \\
\text { 1923; Daft and Marcic, 2006; Drucker, 1955; 1989; 2003; } \\
\text { Emerson, 1912; Fayol, 1916; Follett, 1925; Gantt, 1908; Gilbreth, } \\
\text { 1922; Hellriegel et al., 2008; Owen, 1825; Reese and Porter, 2008; } \\
\text { Simon, 1962; Sheldon, 1923; Taylor, 1911 }\end{array}$ & $\begin{array}{l}\text { Ulrich, Zenger and Smallwood, } \\
1999\end{array}$ \\
\hline
\end{tabular}


This conceptualisation of tasks of management and leadership, as presented in table 1, needs some explanation. The first column indicates the tasks or activities that are presented in the literature. The second column shows which management author refers to the task/activity listed in column 1 . The third column shows the leadership author supporting the task/activity listed in the first column. In drafting column 1, it was interesting to note that not all of the authors use the same labels to identify these themes; neither do they all refer explicitly to all of these themes. Nevertheless, these themes are deemed to be a comprehensive list representing the tasks required to be discharged to ensure the success of the business.

In examining table 1, one may think that a number of tasks/activities, such as decisionmaking and judgement, have been left out. However, the integrated nature of the concepts "management" and "leadership" (separately and collectively) means that some of the tasks/activities listed in table 1 imply a number of interwoven tasks/activities that are not explicitly mentioned. Profit (the norm of successful enterprises) is a function of survival and growth. Survival and growth depend on the opportunities and threats foreseen in the future, which sway management decisions. As such, direction setting is interwoven with survival and growth. Survival and growth also imply morality, specifically resisting short-term financial gain for long-germ survival and growth (see Novicevic et al., 2005). Balancing conflicting interests - personal, business and staff interests - in decisions is also implied and incorporates social responsibility (Barnard, 1938). Mobilising employees is interwoven with goal achievement (part of direction setting), determining performance from the view of both the customers and the organisation, creating and maintaining an environment in which employees can perform and maintain the wealth-creating capacity of the firm. Determining priorities implies decisiveness and resource allocation to meet the goals and objectives of the firm and it flows from those goals. At the same time, the task of determining priorities also addresses coordination to ensure that the total business moves in the same direction. Determining priorities, coordination and mobilising employees are all facilitated by organisation structure. Organisation structure, in turn, is influenced by strategy, which forms part of direction setting. As such, determining priorities is also interwoven with communication, as staff should be informed of the 
focus of the firm to channel their energies accordingly; this also influences mobilisation of employees.

Customer needs and wants are derived from the concept "foresee the future", which is intrinsically interwoven with the environment. This, in turn, links with direction setting and determining priorities, as well as creating an environment within which employees can perform to achieve the goals of the firm. Customer needs and wants are also related to selecting an arena where the firm wants to compete, as well as providing value to customers. Understanding the environment implies adaptation to change, as the environment contains variables that are constantly changing, which may hold opportunities or pose threats to the survival and growth of the firm, both of which are evident from the information base.

The information base also includes record keeping, norms and standards to monitor and control progress, as well as processes and procedures to be followed in executing activities (Church and Alfred, 1912; Gant, 1908; Metcalfe, 1885; Towne, 1886; Gehani, 2002). In turn, these activities have a bearing on productivity in achieving the goals of the firm. Productivity is also influenced by the access to knowledge, skills, assets, resources and processes to provide value to customers. The latter two activities also influence profitability.

This explanation merely illustrates the integrated nature of the management/leadership activities, without providing an exhaustive exegesis of how the activities are intertwined.

The information in table 1 suggests that the management authors, whether pioneers or contemporary contributors, cover all tasks/activities in the literature. Contemporary leadership authors like Ulrich et al. (1999) address most of these tasks. The pioneers in leadership, like Zaleznik (1977) and Kotter (2001), on the other hand, address only a limited number of these tasks, including direction setting (tasks 3-6), communication (task 7) and motivation (tasks 8 and 18-21), generally associated with the higher echelons in the hierarchy. It is not clear from their (Zaleznik and Kotter) works whether 
they see these tasks as interwoven with the tasks set out in the previous paragraph. Furthermore, their assumptions, although not stated explicitly, correspond with Taylor's viewpoint, namely the shop-floor view rather than that of top management.

Figure 1 below illustrates the concepts "management" and "leadership" and their constituent tasks/activities, numbered according to their appearance in table 1 .

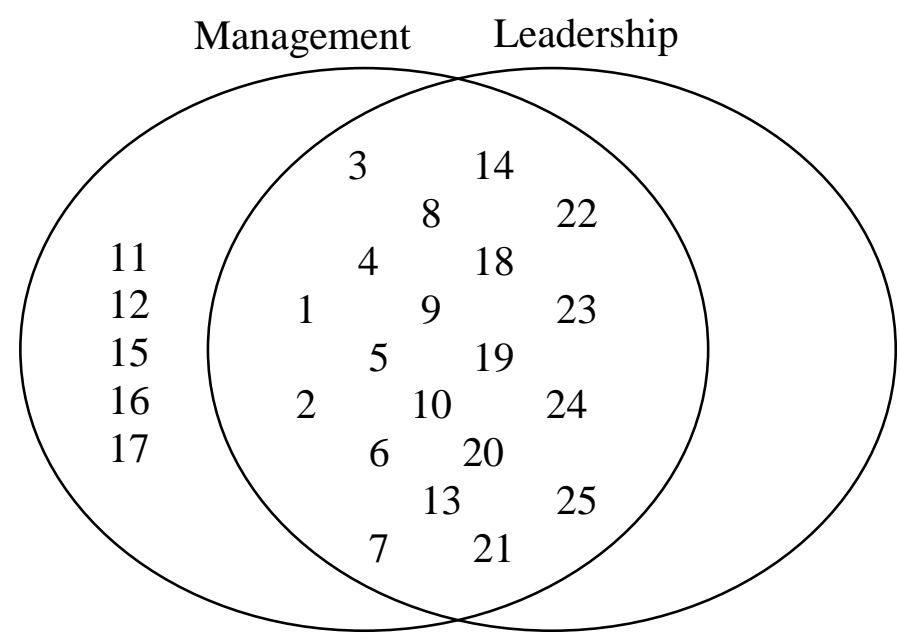

Figure 1: The content of "management" and "leadership" according to the literature, as reflected in table 1

According to figure 1, all of the tasks/activities indicated in table 1 fall within the boundaries of management. Figure 1 shows that leadership tasks overlap with the majority of the tasks addressed by management. Furthermore, unlike management, leadership has no distinct tasks that are exclusively within its boundaries. This observation warrants the question whether leadership is indeed a separate and exalted concept in relation to management. Given these observations, it appears that management is more comprehensive by nature than leadership, as proposed by the leadership pioneers in particular. Even if one takes into consideration the integrated nature of the management/leadership tasks/activities, as set out in table 1 and discussed above, leadership remains without a distinct or separate body. As such, the terms "leadership" and "management" (still) appear to be one and the same. 
The information presented so far suggests that nothing much has changed since the origins and first records of management and leadership. Both terms existed early in history - although they originated in different languages - and are deemed to be synonyms. Both refer to a hierarchical position in the firm that requires special qualities of the incumbent. These terms have been used interchangeably since those early days and are still being used interchangeably today. The perceived difference between the terms may be explained by the observation of Plato, namely that knowing what to do and doing it are two different things. As was pointed out earlier (Bass in Kidwell, 2005), the person in the position of leader/manager needs to have characteristics of both to be successful. Not all persons in a leadership/management position possess the quality of foresight to be able to foresee the future and make prudent decisions. As such, the survival and growth of the firm may be in jeopardy because of the leader/manager's inability to predict the future or place emphasis on significant variables. The same applies to morality, especially balancing short-term financial gain with long-term survival and growth.

The suggestion that not much has changed since the early days of management and leadership is also consistent with the view of Chapman (2001), Fells (2000), Gehani (2002), Hellriegel et al. (2008); Mendenhall et al. (2000), Reese and Porter (2008), Rodriques (2001), Wren, Bedian and Breeze (2002) and Wren (2005) namely that new forms of organisation, which are flexible, horizontally integrated and decentralised, still practise management as originally documented by the pioneers. According to Chapman (2001), judgement and influence are particularly relevant in modern-day organisations.

Another point of relevance is that if it were true that some authors (Kotter, 2001; Zaleznik, 1977) view management from the shop-floor level, then leadership would imply the top management view. To a certain degree, this may explain the difference between management and leadership, as the different hierarchical levels require different tasks/responsibilities/roles. For example, management/leaders in higher echelons of the organisation are more involved in tasks relating to the survival and growth of the organisation, whereas managers in the lower ranks of the organisation are more involved with tasks/activities relating to operational issues, such as creating and 
maintaining an environment within which employees can perform. The lower levels of management/leadership cannot discharge their responsibilities if the top management/leadership has not discharged theirs. This is consistent with the view of Sheldon (1923).

\section{CONCLUSION}

There is a divide in the conceptualisation of the terms "management" and "leadership" in the literature. The basis for this divide is not clear, as both management and leadership roles have a common goal and are concerned with the overall success of the business. As such, this article set out to review a range of works on classical management and leadership to determine their respective contents.

The findings of the literature review demonstrate that management and leadership are inextricably interwoven. All of the tasks identified in the literature reviewed fall within the boundaries of management, and the majority of these tasks overlap with leadership. Management has a few tasks that are not shared by leadership, while leadership has no distinct tasks within its boundary. These findings show that management authors, whether past or current, address most of these tasks. In the case of leadership, the contemporary authors address most of these tasks, while the pioneers address only some. Furthermore, on closer examination, these tasks can be categorised into planning, organising, command, coordination and control, as originally identified by Fayol (1916).

The findings of this study support those of various authors, such as

- Storey and Salaman (2005), who concluded that knowing what is expected of the role and knowledge required to discharge the expected role are problematic.

- McMahon and Carr (1999), who are of the opinion that the current generation of students are reading less of the actual writings of the early scholars and more of what current authors attribute to those early scholars.

- Wren (2005), who holds the view that despite mountains of literature on leadership, very little is conclusive. 
At this stage it should be pointed out that this study was only exploratory in nature and, as such, the findings cannot be generalised. Nevertheless the evidence from the literature demonstrates a need for management and its ultimate relevance. At the same time the findings give rise to a number of questions, most important of which is how practising managers will perceive these concepts.

Implications of the findings of this study include debate regarding how practising managers can know what is expected of them to discharge their responsibilities effectively if the literature, especially contemporary literature, is unclear on the distinction between, and the relevance of, the concepts of management and leadership. This confusion is completely contrary to Fayol's (1916) message, namely that (business) success is due to the "steady application of certain simple principles". Further study is necessary to contribute to clarity on the phenomena "management" and "leadership", since they still seem to be misunderstood, despite centuries of research and publication. Any future study should therefore endeavour to find the "simple principles" that ensure business success, however daunting that may seem.

It is in the interest of the management and leadership community to clarify the confusion surrounding the concepts of "management" and "leadership" in order to prevent diminishing the significance of these concepts, especially management as the literature clearly demonstrates its relevance. The etymology of management and leadership demonstrates that these words originated in different languages, though with the same meaning. The literature review shows that these concepts evolved according to their original meaning and are applied accordingly. These observations show that a common language serves as basis for effective communication, irrespective of the profession - whether one is a practitioner, or an academic, or a researcher.

This article contributed to an increased clarification of the concepts of management and leadership with regard to the meaning that might result in analogous definitions, which, in turn, might contribute to ensuring that the integrity of these concepts, especially management, remain intact and curbing unscientific, unfounded and wild claims in connection with management and leadership. 


\section{REFERENCES}

Armandi, B., Oppedisano, J. and Sherman, H. (2003), "Leadership theory and practice: a 'case' in point”, Management Decision, Vol. 41 No.10, pp. 1076-1088.

Babbage, C. (1832), "On the division of labour" in Merrill, H.F. (Ed.), (1970), Classics in management, [S.1.]: American Management Association, pp. 11-18.

Babbie, E. (2007), The practice of social research, 11th edition, Belmont: Thompson Wadsworth.

Barnard, C.I. (1938), The functions of the executive, Boston: Harvard Business School Press.

Barnard, C.I. (1948), “The nature of leadership”, in Merrill, H.F. (Ed.), (1970), Classics in management, [S.1.]: American Management Association, pp. 432-460.

Bennis, W. and Nanus, B. (1985), Leaders: strategies for taking charge, Dryden, NY: Dryden Press.

Berelson, E. and Bernard, S. (1952), Content analysis in communication research, New York: Free Press.

Bruch, H. and Ghoshal, S. (2004), A bias for action: how effective managers harness their willpower, achieve results and stop wasting time, Boston: Harvard Business School Press.

Burns, J.M. (1978), Leadership, New York: Harper and Row.

Chapman, J.A. (2001), "The work of managers in new contexts", The Journal of Management Development, Vol. 20 No. 1, pp. 55-68. 
Church, A.H. and Alfred, H. (1912), "The principles of management" in Merrill, H.F. (Ed.), (1970), Classics in management, [S.1.]: American Management Association, pp. 169-188.

Collins, J. (2001), Good to great: why some companies make the leap and others don't, New York: HarperCollins.

Creswell, J.W. (2009), Research design: qualitative, quantitative and mixed methods approaches, Thousand Oaks: Sage.

Daft, R.L. (2008), The leadership experience, 4th edition, Mason, OH: Thomson SouthWestern.

Daft, R.L. and Marcic, D. (2008), Management: the new workplace, 6th edition. Mason, $\mathrm{OH}$ : Thomson South-Western.

Drucker, P.F. (1955), The practice of management, London: Heinemann.

Drucker, P.F. (1989), The practice of management, London: Heinemann.

Drucker, P.F. (2003), On the profession of management, Boston: Harvard Business School Press.

Emerson, H. (1912), “The first principle: clearly defined ideals”, in Merrill, H.F. (Ed.), (1970), Classics in management, [S.1.]: American Management Association, pp. 151168.

Fayol, H. (1916), General and industrial management, Translated from the French by Constance Storrs (1949), London: Pitman.

Fells, M.J. (2000), "Fayol stands the test of time", Journal of Management History, Vol. 6 No. 8, pp. 345-360. 
Follett, M.P. (1925), "Management as a profession” in Merrill, H.F. (Ed.), (1970), Classics in management, [S.1.]: American Management Association, pp. 281-294.

Follett, M.P. (1933a), "The essentials of leadership”, in Graham, P. (Ed.), (1995), Mary Parker prophet of management: A celebration of writings from the 1920's", Washington: Beard Books: pp.163-176.

Follett, M.P. (1933b), "Co-ordination", in Merrill, H.F. (Ed.), (1970), Classics in management, [S.1.]: American Management Association, pp. 309-326.

Gantt, H.L. (1908), "Training workmen in habits of industry and co-operation", in Merrill, H.F. (Ed.), (1970), Classics in management, [S.1.]: American Management Association, pp.107-121.

Gehani, R.R. (2002), “Chester Barnard's "executive” and the knowledge based firm”, Management Decision, Vol. 40 No. 10, pp. 980-991.

Ghoshal, S. (2005), "Bad management theories are destroying good management practices", Academy of Management Learning and Education, Vol. 4 No. 1, pp. 75-81.

Gilbreth, L. (1914), in Spiegel, W.R. and Myers, C.E. (Eds), (1953), The writings of the Gilbreths, Homewood, Ill: Irwin.

Gilbreth, F.B. (1922), "Science in management for the one best way to do work", in Merrill, H.F. (Ed.), (1970), Classics in management. [S.1.]: American Management Association, pp. 217-266.

Grace, M. (2003), "Origins of leadership: the etymology of leadership“, in Proceedings of the 2003 annnual conference of the International Leadership Association, in Guadalajara, Jalisco, Mexico, available at 
http://www.ila-net.org/Publications/Proceedings/2003/mgrace.pdf (accessed on 10 June $\underline{2009)}$.

Hellriegel, D., Jackson, S.E., Slocum, J., Staude, G., Amos, T., Klopper, H.B., Louw, L and Oosthuizen, T. (2008), Management: third South African edition, Cape Town: Oxford University Press.

Hodgetts, R.M. (1975), Management, theory, practice and process, Philidelphia, PA: WB Saunders and Co.

Hopf, H.A. (1935), "Management and the optimum", in Merrill, H.F. (Ed.), (1970), Classics in management, [S.1.]: American Management Association, pp. 327-378.

Horner, M. (1997), "Leadership theory: past, present and future“, Team Performance Management, Vol. 3 No. 4, pp. 270-287.

Humphreys, J.H. (2005), "Contextual implications for transformational and servant leadership: a historical investigation“, Management Decision, Vol. 43 No. 10, pp. 14101431.

Humphreys, J.H. and Einstein, W.O. (2003), "Nothing new under the sun: transformational leadership from a historical perspective“, Journal of Management History, Vol. 44 No. 1, pp. 85-95.

Kent, T.W. (2005), "Leading and managing: it takes two to tango", Management Decision, Vol. 43 No. 7/8, pp. 1010-1017.

Kent, T.W., Crotts, J.C. and Azziz, A. (2001), "Four factors of transformational leadership behaviour", Leadership and Business Development Journal, Vol. 22 No. 5, pp. 221-229.

Kidwell, R.E. (2005), “Seven decades of leadership and performance: an interview with Bernard M. Bass“, Journal of Applied Management and Entrepreneurship, July. 
Kirkevold, M. (1997), "Integrative nursing research - an important strategy to further the development of nursing science and nursing practice“, Journal of Advanced Nursing, Vol. 25, pp. 977-984.

Koontz, H. and Weihrich, H. (1988), Management, 9th edition, Singapore: McGrawHill.

Kotter, J.P. (1996), Leading change, Boston: Harvard Business School Press.

Kotter, J.P. (2001), "What leaders really do", Harvard Business Review, Vol. 79, pp. $85-96$.

Lamond, D. (2005), "On the value of management history: absorbing the past to understand the present and inform the future", Management Decision, Vol. 43 No. 10, pp. 1273-1281.

McGregor, D.M. (1966)(a), "The human side of enterprise" in Merrill, H.F. (Ed.), (1970), Classics in management. [S.1.]: American Management Association, pp.461475.

McGregor, D.M. (1966)(b), “The new concepts of management” in Merrill, H.F. (Ed.), (1970), Classics in management, [S.1.]: American Management Association, pp. 476484.

McMahon, D. and Carr, J.C. (1999), "The contributions of Chester Barnard to strategic management theory", Journal of Management History, Vol. 5 No. 5, pp. 228-240.

Mendenhall, M.E., Macomber, J.H. and Cutright, M. (2000), "Mary Parker Follett: prophet of chaos and complexity", Journal of Management History, Vol. 6 No. 4, pp. 191-204. 
Metcalfe, H. (1885), “The science of administration”, in Merrill, H.F. (ed.), (1970), Classics in management, [S.1.]: American Management Association, pp. 37-48.

Mintzberg, H. (1973), The nature of managerial work, New York: Harper and Row.

Moss-Kanter, R. (1997), On the frontiers of management, Boston: Harvard Business School Press.

Nienaber, H. and Roodt, G. (2008), "Management and leadership: buccaneering or science?”, European Business Review, Vol. 20 No. 1, pp. 36-50.

Novicevic, M.N., Davis, W., Dorn, F., Buckley, M.R. and Brown, J.A. (2005), "Barnard's conflict of responsibility for today's perspectives on transformational leadership", Management Decision, Vol. 43 No. 10, pp. 1396-1409.

Novicevic, M.N., Sloan, H., Duke, A., Holmes, E. and Breland, J. (2006), “Customer relationship management: Barnard's foundation”, Journal of Management History, Vol. 12 No. 3, pp. 306-318.

O'Connor, E.S. (2000), "Integrating Follett: history, philosophy and management", Journal of Management History, Vol. 6 No. 4, pp. 167-90.

Owen, R. (1825), “An address to the superintendents of manufacturing”, in Merrill, H.F. (ed.), (1970), Classics in management, [S.1.]: American Management Association, pp. 11-18.

Parayitam, S., White, M.A. and Hough J.R. (2002), “Juxtaposition of Chester I Barnard and Frederick W Taylor: forerunners of management", Management Decision, Vol. 40 No. 10, pp. 1003-1012.

Parker, L.D. and Ritson, P. (2005), "Fads, stereotypes and management gurus: Fayol and Follett today", Management Decision, Vol. 43 No. 10, pp. 1335-1357. 
Payne, S.C., Youngcourt, S.S. and Watrous, K.M. (2006), "Portrayals of F.W. Taylor across textbooks", Journal of Management History, Vol. 12 No. 4, pp. 385-407.

Pearce, C.L., Sims Jr, H.P., Cox, J.F., Ball, G., Schnell, E., Smith, K.A. and Trevino, L. (2003), "Transactors, transformers and beyond: a multi-method development of a theoretical typology of leadership”, Journal of Management Development, Vol. 22 No. 4, pp. 273-307.

Reese, W.D. and Porter, C. (2008), Skills of management, $6^{\text {th }}$ edition, London: Cengage Learning.

Robb, R. (1910), “Organisations as affected by purpose and conditions”, in Merrill, H.F. (ed.), (1970), Classics in management, [S.1.]: American Management Association, pp.133-150.

Rodrigues, C.A. (2001), "Fayol's 14 principles of management then and now: a framework for managing today's businesses", Management Decision, Vol. 39 No. 10, pp. $880-889$.

Rousseau, D.M. (2006), "Is there such a thing as evidence-based management?", Academy of Management Review, Vol. 31 No. 2, pp. 256-269.

Sheldon, O. (1923), “A professional creed for managers”, in Merrill, H.F. (Ed.), (1970), Classics in management, [S.1.]: American Management Association, pp. 267-280.

Simon, H.A. (1962), Administrative behaviour, New York: Macmillan.

Spurgeon, P. and Cragg, R. (2007), "Is it management or leadership?", Clinician in Management, Vol. 15, pp. 123-125.

Stewart, R. (1985), The reality of management, London: Heinemann. 
Storey, J. and Salaman, G. (2005), “The knowledge work of general managers”, Journal of General Management, Vol. 31 No. 2, Winter, pp. 57-73.

Taylor, F.W. (1911), The principles of scientific management, New York: Dover.

Tichy, N.M. (1997), The leadership engine: how winning companies build leaders at every level. New York: Harper-Collins.

Toor, S. and Ofori, G. (2008), "Leadership versus management: how they are different and why", Leadership and Management in Engineering, April, pp. 61-71.

Towne, H. (1886), “The engineer as economist”, in Merrill, H.F. (Ed.), (1970), Classics in management, [S.1.]: American Management Association, 49-56.

Ulrich, D., Zenger, J. and Smallwood, N. (1999), Result-based leadership, Boston: Harvard Business School Press.

Von Krosigk, B. (2007), “A holistic exploration of leadership development”, South African Journal of Business Management, Vol. 38 No. 2, pp. 25-31.

Wagner-Tsukamoto, S. (2007), “An institutional economic reconstruction of scientific management: on the lost theoretical logic of Taylorism", Academy of Management Review, Vol. 32 No. 1, pp. 105-117.

Washbush, J.B. (2005), "There is no such thing as leadership, revisited", Management Decision, Vol. 43 No. 7/8, pp. 1078-1085.

Witzel, M. (2002), Builders and dreamers: the making of management, [S.1.]: Pearson Education. 
Wrege, C.D., Greenwood, R.A. and Hata, S. (1999), "What we do not know about management history: some categories of research methods to uncover management history mysteries” Journal of Management History, Vol. 5 No. 7, pp. 414-424.

Wren, D.A. (2001), "Henri Fayol as strategist: a nineteenth century corporate turnaround" Management Decision, Vol. 39 No. 6, pp. 475-487.

Wren, D.A. (2005), The history of management thought, 5th edition, London: Wiley.

Wren, D.A., Bedeian, A.G. and Breeze, J.D. (2002), “The foundations of Henri Fayol's administrative theory", Management Decision, Vol. 40 No. 9, pp. 906-918.

Zaleznik, A. (1977), "Managers and leaders: are they different?", Harvard Business Review, May-June, pp. 67-78. 